\title{
Synergetic Effects of Plant Extracts and Antibiotics on Vibrio cholerae O1 Strains Isolated From Clinical Specimens
}

\author{
Laure Brigitte Kouitcheu Mabeku ${ }^{1}$, Talla Emmanuel ${ }^{2}$, Jacques Kouam³ ${ }^{3}$, Tize Zra ${ }^{2}$ \\ \& Oyono Essame Jean Louis ${ }^{4}$ \\ ${ }^{1}$ Microbiology and Pharmacology Laboratory, Department of Biochemistry, Faculty of Science, University of \\ Dschang, Dschang, Cameroon \\ ${ }^{2}$ Department of Chemistry, University of Ngaoundéré, Ngaoundéré, Cameroon \\ ${ }^{3}$ Department of Organic Chemistry, Faculty of Sciences, University of Yaoundé, Yaoundé, Cameroon \\ ${ }^{4}$ Institute of Medical Research and Medicinal Plants Studies (IMPM), Yaoundé, Cameroon \\ Correspondence: Laure Brigitte Kouitcheu Mabeku, Microbiology and Pharmacology Laboratory, Department of \\ Biochemistry, Faculty of Science, University of Dschang, P. O. Box 67, Dschang, Cameroon. Tel: \\ 237-7778-8002. E-mail: lauremabek@yahoo.fr
}

Received: January 9, 2013 Accepted: May 17, 2013 Online Published: June 17, 2013

doi:10.5539/ijb.v5n3p64 URL: http://dx.doi.org/10.5539/ijb.v5n3p64

\begin{abstract}
The objective of this study was to evaluate in vitro synergy of extracts from Picralima nitida, Cylicodiscus gabunensis, Cassia arereh and Trichilia emetica and known antimicrobial agents against clinical isolate of vibrio cholerae.

The in vitro antibacterial activity of plant-extracts was evaluated alone and in combination with standard antibiotics against Vibrio cholerae using disc-diffusion and microdilution method.

Only antibiotics acting by inhibiting proteins synthesis shown strong bactericidal activity with inhibition zone diameter ranging from $11 \pm 0.0$ to $26 \pm 0.6 \mathrm{~mm}$. we also noticed that methanolic extract of Cassia arereh and Trichilia emetica and ethyl acetate extract of Cassia arereh contain bioactive compounds. These extracts were effective anticholeric agents with MIC ranging between 12.207 and $97.656 \mu \mathrm{g} / \mathrm{ml}$ and MBC between 48.828 and $781.25 \mu \mathrm{g} / \mathrm{ml}$. Cassia arereh extract showed the greatest activity with MIC and MBC values of 12.207 and 48.828 $\mu \mathrm{g} / \mathrm{ml}$ respectively. Synergism was observed between antimicrobial agents and the best anticholeric plant-extract with significant reduction in the MICs of antibiotics against the strains tested. Administration of both compounds together resulted in an MIC ranging from 0.078 to $10 \mu \mathrm{g} / \mathrm{ml}$ which represents a 2 to 16 -fold reduction in the MICs of the antibiotics tested alone. This change in MIC was noticed even with antibiotics showed weak antibacterial activity.
\end{abstract}

Keywords: synergetic effects, antibiotics, plant-extracts, $V$. Cholerae $\mathrm{O} 1$

\section{Introduction}

Cholera is an acute diarrheal disease caused by Gram negative bacillus Vibrio cholerae. Although more than 100 serogroups exist, only two cause epidemic Cholera; V. cholerae $\mathrm{O} 1$ and $V$. cholerae 0139 . Cholera is a disease that occurs in low-income regions of the world where sanitation and food and water hygiene are inadequate. Imported cases occasionally occur in travelers returning from endemic areas (WHO, 2009). In areas without clean water or sewage disposal, cholera can spread quickly and have a case fatality rate of as high as $50 \%$ in vulnerable group with limited medical care (WHO, 2010). Annual global figures reported to WHO included 221,226 cases and 4946 deaths from 45 countries. The majority of cases (98\%) were reported from Africa where an outbreak that started in 2008 and lasted for almost a year, spread to South Africa and Zambia. WHO (2009) estimates the actual global burden of disease as 3 to 5 million cholera cases and 100,000 to 130,000 deaths each year. Treatment which consisted on a rapid fluid replacement with a balanced solution of sugar, electrolytes and water should be started urgently (Heymann et al., 2004; Sack et al., 2004). Cases may also be treated with antibiotics in order to improve symptoms and decrease the intestinal excretion of the organism. Some antibacterial agents kill bacteria (bactericidal), while others only inhibit their growth (bacteriostatic). There are four main target sites for antibacterial action: cell wall synthesis, protein synthesis, nucleic acid synthesis and 
cell membrane function. Usually a tetracycline is used if the organism is sensitive. Tetracycline inhibits proteins synthesis by preventing aminoacyl transfert RNA from entering the acceptor site on the ribosome. Like tetracycline, a range of antibiotics act as inhibitors of protein synthesis by interfering with one or more step of the processes such as preventing the formation of initiation complexes, preventing peptide bond synthesis, preventing the release of tRNA after peptide bond formation. WHO (2010) reports the emergence of new, apparently more virulent strains of $V$. cholerae $\mathrm{O} 1$ which now predominate in parts of Africa and Asia, and the emergence and spread of antibiotic resistant strains. Combined antibiotic therapy has been shown to delay the emergency of bacteria resistance and may also produce desirable synergistic effects in the treatment of bacterial infection. Drug synergism between known antibiotics and bioactive plant extracts is a novel concept and could be beneficial (synergistic or additive interaction) or deleterious (antagonistic or toxic outcome). Many readily available plants in Cameroon are used in traditional folklore medicine for the treatment of gastrointestinal disorders such as cholera, diarrhea and dysentery. However, several of them have not been investigated for a pharmacological point of view to demonstrate their antibacterial properties, which could support their use as anticholeric or antidiarrheal remedies in traditional medicine.

The objective of the present study was to judge the multi-drug resistance patterns of $V$. cholerae serogroup O1 isolated from an epidemic choleric diarrhea that occurred in the extreme north region of Cameroon in 2009 and to evaluate drug synergism between weak or non active known antibiotics and bioactive plant extracts against this microorganism.

\section{Materials and Methods}

\subsection{Plant Materials}

We ethnobotanically selected four Cameroonian medicinal plants traditionally used in the treatment of gastrointestinal disorders Picralima nitida (Apocynaceae), Cylicodiscus gabunensis (Mimosaceae), Cassia arereh (Caesalpiniaceae) and Trichilia emetica (Meliaceae) for anticholeric screening. The plants were collected by the authors in the center and north region of Cameroon. The botanical identification of the plant samples was carried out by a botanist and the voucher specimens are conserved at the National Herbarium Yaoundé.

\subsection{Microorganisms}

The clinical strain of $V$. cholerae serogroup $\mathrm{O} 1$ was used. The strain was isolated and identified by Centre Pasteur of Yaoundé from an epidemic choleric diarrhea that occurred in the extreme north region of Cameroon in July 2009.

\subsection{Other Materials and Reagents}

Commercially available disks were used for antimicrobial susceptibility test. they were disc of inhibitors of cell-wall (the $\beta$ lactams ampicilin $10 \mu \mathrm{g}$, amoxycillin $10 \mu \mathrm{g}$, amoxycillin plus clavulanic acid $20 / 10 \mu \mathrm{g}$; the cephalosporin cefoxitin $30 \mu \mathrm{g}$ and the glycopeptides vancomycin $30 \mu \mathrm{g}$ ); inhibitors of cytoplasmic membrane function (colistin $10 \mu \mathrm{g}$ ); inhibitors of proteins synthesis (streptomycin $10 \mu \mathrm{g}$, gentamicin $10 \mu \mathrm{g}$, tobramycin $2 \mu \mathrm{g}$, kanamycin $30 \mu \mathrm{g}$, netilmicin $30 \mu \mathrm{g}$, spectinomycin $25 \mu \mathrm{g}$, chloranphenicol $30 \mu \mathrm{g}$, doxycycline monohydrate $30 \mu \mathrm{g}$, clindamycin $10 \mu \mathrm{g}$, erythromycin $15 \mu \mathrm{g}$, and dibecacin $10 \mu \mathrm{g}$ ) and inhibitors of nucleic-acid synthesis (sulfamethozadole plus trimetoprim $25 \mu \mathrm{g}$, nitrofurantoin $100 \mu \mathrm{g}$ ). Antibiotics used in microdilution method were gentamicin sulfate (Sigma-Aldrich, St. Louis, USA), kanamycin, netilmicin sulfate, dibecacin, erythromycin, spectinomycin, streptomycin, clindamycin (Chemos Gmbh, Germany), chloramphenicol (Sigma-Aldrich, St. Quentin Fallavier, France), tetracycline hydrochloride (Merck KGaA, Darmstadt, Germany) and tobramycin (Sigma-Aldrich Corporation, USA).

\subsection{Preparation of Extracts}

Plant extracts were prepared by macerating $500 \mathrm{~g}$ of air-dried plant part with $2500 \mathrm{ml}$ of the appropriate solvent in a Soxhlet apparatus for $18 \mathrm{~h}$ (Thakurta et al., 2007). The extract was then filtered and concentrated in a rotary vacuum evaporator. The extract was further concentrated by allowing it to stand overnight in an oven at $30^{\circ} \mathrm{C}$. The dried material was stored at $-20^{\circ} \mathrm{C}$ until use. The yield of each extract is shown in Table 1 .

\subsection{Determination of Multi-Drug Resistance Patterns of the Strain}

In order to judge their multi-drug resistance patterns, antimicrobial susceptibility testing was performed using disc diffusion assay against $V$. Cholerae $\mathrm{O} 1$ with 19 commercially available disks of antibiotics (Bauer et al., 1996). $100 \mu \mathrm{l}$ of the suspension of $V$. Cholerae O1 containing $10^{8} \mathrm{CFU} \mathrm{ml}^{-1}$ prepared from an overnight culture was used to seed each prepared and dried Mueller Hinton agar plate. The discs were arranged and firmly pressed on the agar surface of each seeded plate. These plates, after staying at $4^{\circ} \mathrm{C}$ for 2 hours were incubated aerobically at 
$37^{\circ} \mathrm{C}$ for 24 hours. The strain isolate was considered susceptible, less susceptible, or resistant to a particular antimicrobial agent on the basis of the diameters of the inhibitory zones that matched the criteria of the manufacturer's interpretation table, which followed the recommendations of the National Committee for Clinical Laboratory Standards (NCCLS 2002).

\subsection{Evaluation of the Anticholeric Activity of Plant-Extract (Herbal-Drug)}

Disc diffusion assay: a solution of $200 \mathrm{mg} \mathrm{ml}^{-1}$ of each plant-extract was prepared and serially diluted from that concentration to $1.562 \mathrm{mg} \mathrm{ml}^{-1}$. Sterile paper disc of $6 \mathrm{~mm}$ were impregnated with $10 \mu \mathrm{l}$ of each plant-extract dilution (Edward, 1980). The different masses of extract evaluated were 20, 17.5, 15, 12.5, 7.5, 5, 2.5, 1.25, 0.625, 0.3125 and $0.156 \mathrm{mg} /$ disc. Negative control was also prepared by impregnating paper disc with solvent used to dissolve the plant extract. These paper discs were kept in an incubator at $37^{\circ} \mathrm{C}$ for 24 hours to evaporate the solvent. Antimicrobial tests were then carried out as described above. Antimicrobial activity was evaluated by measuring the inhibition diameter (DI) zone around the tested microorganism. The mean DI zone for each plant-extract preparation was determined as the average of three independent experiments.

\subsection{Determination of the Inhibition Parameters of Plant-Extracts}

The Minimum inhibitory concentration (MIC) values of herbal-drug which has shown an anticholeric activity according to disc diffusion assay were determined. The broth microdilution method was used (NCCLS, 1999). Liquid cultures of $V$. cholerae bacteria to a density of $10^{5} \mathrm{CFU} / \mathrm{ml}$ were prepared by suspension in sterile hypersalted alkaline peptone water supplemented with $1 \%$ saccharose $(\mathrm{w} / \mathrm{v})$ with red phenol as a colour indicator (HAPPS1\%). 96-well flat-bottom microplates were prepared by dispensing $180 \mu 1$ of the inoculated broth into each well. A $20 \mu \mathrm{l}$ aliquot of each plant extract was added and successive twofold dilutions of each plant- extract in HAPPS1\% medium ranging from 0.0952 to $6250 \mu \mathrm{g} \mathrm{ml}^{-1}$ was tested. One well was considered as growth control since no extract solution was added. The final volume of each well was $200 \mu$. The bacterial growth was indicated by the colour change of the well content from the red to yellow. The MIC was defined as the lowest concentration of the extract which inhibits the growth of microorganism. The MBC were determined by platting 5 $\mu 1$ sample from red wells on Mueller Hinton agar without extract. The MBC was the concentration at which there was not microbial growth.

\subsection{Determination of the Inhibition Parameters of Standard Drugs}

The minimum inhibitory concentration values of some standard antibiotics which have shown anticholeric activity according to disc diffusion assays were determined. We also evaluated the anticholeric activity of other antibiotics acting by inhibiting the protein synthesis which were not active according to disc diffusion assay. Those antibiotics were gentamicin sulfate, kanamycin, netilmicin sulfate, dibecacin, erythromycin, and spectinomycin, and chloramphenicol, tetracycline hydrochloride for the active one; streptomycin, clindamycin and tobramycin for the non active one. The broth microdilution method as described above was used with HAPPS $1 \%$ as culture media. A scalar dilution of each standard drug ranging from 0.0012 to $160 \mu \mathrm{g} \mathrm{ml}^{-1}$ was tested. The MIC and the MBC were determined as described above.

\subsection{Determination of the Inhibition Parameters of Herbal-Drug in Combination With Standard Drugs}

The anticholeric activity of standard and herbal drugs combination was carry in order to check for any synergetic effect. Active or no active antibiotics acting by inhibition of proteins synthesis were used in association. The reason of this choice was the fact that according to the disc diffusion assay the strain of $V$. Cholerae used in this study was sensitive only to those types of antibiotics. Different combinations were then made with antibiotics and the herbal-drug with the greatest antimicrobial activity. Those combinations were ethyl acetate extract of Cassia arereh (Cassia AE) with gentamicin sulfate, kanamycin, netilmicin, chloramphenicol, erythromycin, spectinomycin, doxycycline monohydrate, dibecacin, tobramycin, clindamycin and streptomycin. The broth microdilution method as described above was used with HAPPS $1 \%$ as culture media. A two-fold serial dilutions of each antibiotic ranging from MIC to MIC/64 for the active one were mixed together with a fixed amount of Cassia AE equal to it MIC value. For the no active antibiotics, the concentrations tested were ranging from 5 to $320 \mu \mathrm{g} \mathrm{ml}^{-1}$ in combination with the same fixed amount of Cassia AE. The antibiotics were serial diluted in HAPPS $1 \%$ into a 96-well round bottom sterile plates and the plant extract solution separately prepared in test tubes were added. Then $V$. Cholerae $\mathrm{O} 1$ culture containing $10^{5}$ bacteria were distributed into wells containing various concentrations of the different compounds. The inoculated 96-well round bottom was incubated aerobically at $37^{\circ} \mathrm{C}$ for 24 hours. The amounts of the antibiotic required in combination to produce the minimum inhibitory concentrations were calculated. 


\section{Results}

Plant species, local names, parts used, voucher specimen numbers and the yield of the extraction are listed in Table 1.

Table 1. List of plant species with relevant information

\begin{tabular}{|c|c|c|c|c|}
\hline $\begin{array}{l}\text { Species } \\
\text { (Family) }\end{array}$ & $\begin{array}{l}\text { Local name } \\
\text { (parts of plant used) }\end{array}$ & $\begin{array}{l}\text { Solvent of extraction } \\
\text { (yield) }\end{array}$ & Voucher number & Traditional uses \\
\hline $\begin{array}{l}\text { Picralima nitida } \\
\text { (Apocynaceae) }\end{array}$ & Eban (Fruit bark) & Methanol (5\%) & 2136/SRFK. & $\begin{array}{l}\text { Malaria and male sexual impotence, } \\
\text { dysmenorrheal and gastrointestinal } \\
\text { disorder (Adjanohoun et al., 1996). }\end{array}$ \\
\hline $\begin{array}{l}\text { Cylicodiscus gabunensis } \\
\text { (Mimosaceae) }\end{array}$ & Adoum (stem bark) & $\begin{array}{l}\text { Ethyl acetate } \\
(10.02 \%)\end{array}$ & 21574/SRF/Cam & $\begin{array}{l}\text { Gastro-intestinal disorders, headache and } \\
\text { rheumatism } \\
\text { (Adjanohoun et al., 1996). }\end{array}$ \\
\hline $\begin{array}{l}\text { Cassia arereh } \\
\text { (Caesalpiniaceae) }\end{array}$ & (Leaves) & $\begin{array}{l}\text { Methanol (3\%) } \\
\text { Ethyl acetate }(4.5 \%)\end{array}$ & 39931/HNC. & $\begin{array}{l}\text { indigestion, skin disease, fungal infection, } \\
\text { gastro-intestinal disorders (Kochar, 1981; } \\
\text { Abo et al, 1998). }\end{array}$ \\
\hline Trichilia emetica (Meliaceae) & $\begin{array}{l}\text { stem bark } \\
\text { root bark }\end{array}$ & $\begin{array}{l}\text { Methanol }(5 \%) \\
\text { Ethyl acetate }(22.06 \%)\end{array}$ & 20886/SRF/Cam & $\begin{array}{l}\text { Malaria, cough, Gastrointestinal disorder, } \\
\text { skin disease, gastritis, asthma, } \\
\text { dysmenorhea, cirrhosis (Diallo, 2000). }\end{array}$ \\
\hline
\end{tabular}

The results of the tests are presented in Tables $2-5$. The result of the multi-drug resistance patterns assay shown that the tested strain was resistant to all the tested antibiotics acting by inhibiting the cell-wall or cytoplasmic membrane function or by inhibiting nucleic-acid synthesis (Table 2). Only the inhibitors of proteins synthesis shown strong bactericidal activity with MIC and MBC ranging from 0.156 to $160 \mu \mathrm{g} \mathrm{ml}^{-1}$ and from 0.625 to 160 $\mu \mathrm{g} \mathrm{ml}^{-1}$ respectively. But tobramycin, streptomycin and clindamycin although they are acting by the same way have not shown any anticholeric activity. These observation may be explain by the fact that inhibitors of proteins synthesis acting in different step of the process.

Table 2. Multi-drug resistance patterns of the strain $V$. cholerae $\mathrm{O} 1$ used

\begin{tabular}{|c|c|c|c|c|c|c|c|c|c|c|c|c|c|c|c|c|c|c|c|}
\hline \multirow{2}{*}{ Antibiotic } & \multicolumn{11}{|c|}{ inhibitors of proteins synthesis } & \multicolumn{2}{|c|}{$\begin{array}{l}\text { inhibitors } \\
\text { of nucleic } \\
\text { acid } \\
\text { synthesis }\end{array}$} & \multicolumn{6}{|c|}{$\begin{array}{l}\text { inhibitors of cell-wall or } \\
\text { cytoplasmic membrane function }\end{array}$} \\
\hline & Di & $\mathrm{G}$ & $\mathrm{Er}$ & $\mathrm{K}$ & $\mathrm{Nt}$ & $\mathrm{Sp}$ & $\mathrm{Ch}$ & Do & $\mathrm{Cl}$ & To & St & ST & $\mathrm{Nf}$ & Ap & $\mathrm{Am}$ & Ac & $\mathrm{Cf}$ & $\mathrm{V}$ & Co \\
\hline$\Phi(\mathbf{m m})$ & $16 \pm 0.6$ & $14 \pm 0.3$ & $14 \pm 0.3$ & $11 \pm 0$ & $26 \pm 0.6$ & $12 \pm 0.3$ & $18 \pm 0.3$ & $18 \pm 0.6$ & - & - & - & - & - & - & - & - & - & - & - \\
\hline
\end{tabular}

Each value was expressed as the mean \pm SD of triplicate experiments. $\Phi$ : Inhibition diameter; -: $\Phi=6 \mathrm{~mm}$.

Ampicilin (Ap) amoxicillin (Am) amoxycillin plus clavulanic acid (AC), cefoxitin (Cf) vancomycin (V), colistin $(\mathrm{Co})$, streptomycin $(\mathrm{St})$, gentamicin $(\mathrm{G})$,tobramycin $(\mathrm{To})$, kanamycin $(\mathrm{K})$, netilmicin $(\mathrm{Nt})$, spectinomycin $(\mathrm{Sp})$, chloramphenicol $(\mathrm{Ch})$, doxycycline monohydrate (Do), clindamycin $(\mathrm{Cl})$, erythromycin $(\mathrm{Er})$; sulfamethozadole plus trimetoprim (ST), nitrofurantoin (Nf), dibecacin (Di).

The results obtained using disc-diffusion method demonstrate that methanolic and ethyl acetate extract of Cassia arereh and methanolic extract of Trichilia emetica stem bark contain bioactive compounds (Table 3). These extracts were effective anticholeric agents with MIC ranging between 12.207 and $97.656 \mu \mathrm{g} / \mathrm{ml}$ and MBC between 48.828 and $781.25 \mu \mathrm{g} / \mathrm{ml}$. Among these, ethyl acetate extract of Cassia arereh showed the greatest activity with MIC and MBC values of 12.207 and $48.828 \mathrm{mg} / \mathrm{ml}$ respectively (Table 4). Consequently this plant extract was choosing to carry anticholeric assay in combination with antibiotics (Table 5). A fixed amount of the extract equal to his MIC was used $(12.207 \mu \mathrm{g} / \mathrm{ml})$. 
Table 3. inhibition diameter obtained with plant-extracts against $V$. Cholerae $\mathrm{O} 1$

\begin{tabular}{|c|c|c|c|c|c|c|c|c|c|c|c|c|}
\hline \multirow{2}{*}{ Plant-extract } & \multicolumn{12}{|c|}{ Concentration of extract/disc (mg) } \\
\hline & 20 & 17.5 & 15 & 12.5 & 10 & 7.5 & 5 & 2.5 & 1.25 & 0.625 & 0.3125 & 0.156 \\
\hline Cassia $\mathrm{Me} \mathrm{OH}$ & $14.33 \pm 0.47$ & $12.33 \pm 0.47$ & $12.33 \pm 0.47$ & $11.33 \pm 0.47$ & $10.33 \pm 0.47$ & $10 \pm 0.0$ & $9.66 \pm 0.47$ & $9.33 \pm 0.47$ & $9.33 \pm 0.47$ & $8.33 \pm 0.47$ & $8 \pm 00$ & $7.33 \pm 0.47$ \\
\hline Cassia AE & $18 \pm .0 .81$ & $17 \pm 0.81$ & $15.33 \pm 0.47$ & $13.66 \pm 0.47$ & $13 \pm 0.0$ & $12.33 \pm 0.47$ & $12.33 \pm 0.4$ & $11.33 \pm 0.47$ & $11 \pm 0.0$ & $10 \pm 0.0$ & $8 \pm 0.0$ & $7.33 \pm 0.47$ \\
\hline Trih.c MeOH & $16.33 \pm 0.47$ & $16 \pm 0.81$ & $14.33 \pm 0.47$ & $13.66 \pm 0.47$ & $13.33 \pm 0.94$ & $13.33 \pm 0.47$ & $12 \pm 0.0$ & $9.66 \pm 0.47$ & $8 \pm 0.81$ & 7 & 7 & 7 \\
\hline Trich. EA & - & - & - & - & - & - & - & - & - & - & - & - \\
\hline Picr. N & - & - & - & - & - & - & - & - & - & - & - & - \\
\hline Cyl. G & - & - & - & - & - & - & - & - & - & - & - & - \\
\hline
\end{tabular}

Each value was expressed as the mean $\pm \mathrm{SD}$ of triplicate experiments.

-: $\Phi=6 \mathrm{~mm}$; Cassia Me OH: methanolic extract of Cassia arereh; Cassia AE: ethyl acetate extract of Cassia arereh; Trich. MeOH: methanolic extract of Trichilia emetica stem bark; Trich. EA: ethyl acetate extract of Trichilia emetic stem root; Picr. N: methanolic extract of Picralima nitida fruit ring; Cyl G: ethyl acetate extract of Cylicodiscus gabunensis stem bark.

Table 4. MIC and MBC values of drugs against $V$. cholerae using microdilution assay

\begin{tabular}{|c|c|c|c|c|c|c|c|c|c|c|c|c|c|c|}
\hline Herbal or standard Drug & Cassia M & Cassia A & Tric. Me & Do & $\mathbf{G}$ & Nt & Ch & $\mathbf{E r}$ & To & $\mathrm{Cl}$ & St & Sp & Di & $\mathbf{k}$ \\
\hline MIC $\left(\mu \mathrm{g} \mathrm{ml}^{-1}\right)$ & 97.656 & 12.207 & 24.414 & 2.5 & 10 & 0.156 & 5 & 10 & $>160$ & $>160$ & $>160$ & 20 & 5 & 40 \\
\hline $\operatorname{MBC}\left(\mu \mathrm{g} \mathrm{ml}^{-1}\right)$ & 781.25 & 48.828 & 97.656 & 5 & 20 & 0.625 & 10 & 40 & $>160$ & $>160$ & $>160$ & 80 & 5 & 160 \\
\hline
\end{tabular}

Streptomycin (St), gentamicin(G), tobramycin (To), kanamycin (K), netilmicin (Nt), spectinomycin (Sp), chloramphenicol $(\mathrm{Ch})$, doxycycline monohydrate (Do), clindamycin $(\mathrm{Cl})$, erythromycin (Er), dibecacine (Di); Cassia Me: methanolic extract of Cassia arereh.; Cassia A: ethyl acetate extract of Cassia arereh; Tric. Me: methanolic extract of Trichilia emetica stem bark.

Interactions between antimicrobial agents and plant extract showed synergistic effects through significant reduction in the MICs of the tested antibiotics against $V$. cholerae (Table 5). Administration of both compounds together resulted in an MIC value of $0.078,0.156,0.625,0.625,1.25,2.5$ and $10 \mu \mathrm{g} / \mathrm{ml}$ respectively for netilmicin, doxycycline monohydrate, chloramphenicol, dibecacin, erythromycin, kanamycin and spectinomycin, which represents a 2, 16, 8, 8, 8, 16, and 2-fold reduction in the MICs of the above mentioned antibiotics respectively. Despite that clindamycin and streptomycin showed not anticholeric effect, the interactions between these antibiotics and cassia EA were mainly additive against $V$. cholerae. The MIC values in combination were 10 and $40 \mu \mathrm{g} / \mathrm{ml}$ respectively for clindamycin and streptomycin, which represents a 16 and 4 -fold reduction in the MIC of these antibiotics. These results were in agreement with a previous report who mentioned a synergetic effect even the antibiotic did not show any activity by itself (Nascimento et al., 2000).

Table 5. Minimum inhibitory concentration of antibiotics alone and in combination with cassia EA extract against $V$. cholerae using microdilution method 


\begin{tabular}{|c|c|c|c|c|c|c|c|c|}
\hline $\begin{array}{l}\text { Antibiotic/plant } \\
\text { extract }\end{array}$ & $\begin{array}{c}\text { MIC } \\
(\mu \mathrm{g} / \mathrm{ml})\end{array}$ & $\begin{array}{c}\text { Minimum fold } \\
\text { inhibition for } V \text {. } \\
\text { cholerae strain }\end{array}$ & $\begin{array}{l}\text { Antibiotic/plant } \\
\text { extract }\end{array}$ & $\begin{array}{c}\text { MIC } \\
(\mu \mathrm{g} / \mathrm{ml})\end{array}$ & $\begin{array}{c}\text { Minimum fold } \\
\text { inhibition for } V \text {. } \\
\text { cholerae strain }\end{array}$ & $\begin{array}{l}\text { Antibiotic/plant } \\
\text { extract }\end{array}$ & $\begin{array}{c}\mathrm{MIC} \\
(\mu \mathrm{g} / \mathrm{ml})\end{array}$ & $\begin{array}{l}\text { Minimum fold } \\
\text { inhibition for } V \text {. } \\
\text { cholerae strain }\end{array}$ \\
\hline $\begin{array}{l}\text { Gentamicin } \\
\text { (Genta) }\end{array}$ & 10 & & $\begin{array}{l}\text { Erythromycin } \\
\text { (Ery) }\end{array}$ & 10 & & $\begin{array}{l}\text { Kanamycin } \\
\text { (Kana) }\end{array}$ & 40 & \\
\hline $\begin{array}{l}\text { Cassia EA + } \\
\text { Genta }(\mathrm{MIC} / 1)\end{array}$ & 10 & 1 & $\begin{array}{l}\text { Cassia EA + Ery } \\
(\mathrm{MIC} / 1)\end{array}$ & 1.25 & 8 & $\begin{array}{l}\text { Cassia EA +kana } \\
(\mathrm{MIC} / 1)\end{array}$ & 2.5 & 16 \\
\hline $\begin{array}{l}\text { Cassia EA + } \\
\text { Genta }(\mathrm{MIC} / 2)\end{array}$ & 10 & 1 & $\begin{array}{l}\text { Cassia EA + Ery } \\
(\mathrm{MIC} / 2)\end{array}$ & 1.25 & 8 & $\begin{array}{l}\text { Cassia EA +kana } \\
(\mathrm{MIC} / 2)\end{array}$ & 5 & 8 \\
\hline $\begin{array}{l}\text { Cassia EA }+ \\
\text { Genta }(\mathrm{MIC} / 4)\end{array}$ & 10 & 1 & $\begin{array}{l}\text { Cassia EA + Ery } \\
(\mathrm{MIC} / 4)\end{array}$ & 2.5 & 4 & $\begin{array}{l}\text { Cassia EA +kana } \\
(\mathrm{MIC} / 4)\end{array}$ & 10 & 4 \\
\hline $\begin{array}{l}\text { Cassia EA + } \\
\text { Genta }(\mathrm{MIC} / 8)\end{array}$ & 10 & 1 & $\begin{array}{l}\text { Cassia EA + Ery } \\
(\mathrm{MIC} / 8)\end{array}$ & 10 & 1 & $\begin{array}{l}\text { Cassia EA +kana } \\
(\mathrm{MIC} / 8)\end{array}$ & 40 & 1 \\
\hline $\begin{array}{l}\text { Cassia EA + } \\
\text { Genta }(\mathrm{MIC} / 16)\end{array}$ & 10 & 1 & $\begin{array}{l}\text { Cassia EA + Ery } \\
(\mathrm{MIC} / 16)\end{array}$ & 10 & 1 & $\begin{array}{l}\text { Cassia EA +kana } \\
(\mathrm{MIC} / 16)\end{array}$ & 40 & 1 \\
\hline $\begin{array}{l}\text { Cassia EA + } \\
\text { Genta }(\mathrm{MIC} / 32)\end{array}$ & 10 & 1 & $\begin{array}{l}\text { Cassia EA + Ery } \\
(\mathrm{MIC} / 32)\end{array}$ & 10 & 1 & $\begin{array}{l}\text { Cassia EA + kana } \\
(\mathrm{MIC} / 32)\end{array}$ & 40 & 1 \\
\hline $\begin{array}{l}\text { Cassia EA + } \\
\text { Genta }(\mathrm{MIC} / 64)\end{array}$ & 10 & 1 & $\begin{array}{l}\text { Cassia EA + Ery } \\
(\mathrm{MIC} / 64)\end{array}$ & 10 & 1 & $\begin{array}{l}\text { Cassia EA +kana } \\
(\mathrm{MIC} / 64)\end{array}$ & 40 & 1 \\
\hline $\begin{array}{l}\text { Spectinomycin } \\
\text { (Spect) }\end{array}$ & 20 & & Netilmicine (Net) & 0.156 & & $\begin{array}{l}\text { Doxycycline } \\
\text { (Doxy) }\end{array}$ & 2.5 & \\
\hline $\begin{array}{l}\text { Cassia EA + Spect } \\
(\mathrm{MIC} / 1)\end{array}$ & 10 & 2 & $\begin{array}{l}\text { Cassia EA + Net } \\
(\mathrm{MIC} / 1)\end{array}$ & 0.078 & 2 & $\begin{array}{l}\text { Cassia EA + Doxy } \\
(\mathrm{MIC} / 1)\end{array}$ & 0.1562 & 16 \\
\hline $\begin{array}{l}\text { Cassia EA + Spect } \\
(\mathrm{MIC} / 2)\end{array}$ & 10 & 2 & $\begin{array}{l}\text { Cassia EA + Net } \\
(\mathrm{MIC} / 2)\end{array}$ & 0.078 & 2 & $\begin{array}{l}\text { Cassia EA + Doxy } \\
(\mathrm{MIC} / 2)\end{array}$ & 0.312 & 8 \\
\hline $\begin{array}{l}\text { Cassia EA + Spect } \\
(\mathrm{MIC} / 4)\end{array}$ & 10 & 2 & $\begin{array}{l}\text { Cassia EA + Net } \\
(\mathrm{MIC} / 4)\end{array}$ & 0.078 & 2 & $\begin{array}{l}\text { Cassia EA + Doxy } \\
(\mathrm{MIC} / 4)\end{array}$ & 0.312 & 8 \\
\hline $\begin{array}{l}\text { Cassia EA + Spect } \\
(\mathrm{MIC} / 8)\end{array}$ & 20 & 1 & $\begin{array}{l}\text { Cassia EA + Net } \\
(\mathrm{MIC} / 8)\end{array}$ & 0.156 & 1 & $\begin{array}{l}\text { Cassia EA + Doxy } \\
(\mathrm{MIC} / 8)\end{array}$ & 0.312 & 8 \\
\hline $\begin{array}{l}\text { Cassia EA + Spect } \\
(\mathrm{MIC} / 16)\end{array}$ & 20 & 1 & $\begin{array}{l}\text { Cassia EA }+ \text { Net } \\
(\mathrm{MIC} / 16)\end{array}$ & 0.156 & 1 & $\begin{array}{l}\text { Cassia EA + Doxy } \\
(\mathrm{MIC} / 16)\end{array}$ & 2.5 & 1 \\
\hline $\begin{array}{l}\text { Cassia EA + Spect } \\
(\mathrm{MIC} / 32)\end{array}$ & 20 & 1 & $\begin{array}{l}\text { Cassia EA + Net } \\
(\mathrm{MIC} / 32)\end{array}$ & 0.156 & 1 & $\begin{array}{l}\text { Cassia EA + Doxy } \\
(\mathrm{MIC} / 32)\end{array}$ & 2.5 & 1 \\
\hline $\begin{array}{l}\text { Cassia EA + Spect } \\
(\mathrm{MIC} / 64)\end{array}$ & 20 & 1 & $\begin{array}{l}\text { Cassia EA + Net } \\
(\mathrm{MIC} / 64)\end{array}$ & 0.156 & 1 & $\begin{array}{l}\text { Cassia EA + Doxy } \\
(\mathrm{MIC} / 64)\end{array}$ & 2.5 & 1 \\
\hline Dibecacine (Dibe) & 5 & & $\begin{array}{l}\text { Chloramphenicol } \\
\text { (Chl) }\end{array}$ & 5 & & Tobramycin (To) & $>160$ & \\
\hline $\begin{array}{l}\text { Cassia EA + Dibe } \\
(\mathrm{MIC} / 1)\end{array}$ & 0.625 & 8 & $\begin{array}{l}\text { Cassia EA + Chl } \\
(\mathrm{MIC} / 1)\end{array}$ & 0.625 & 8 & $\begin{array}{l}\text { Cassia EA + To }(5 \\
\mu \mathrm{g} / \mathrm{ml})\end{array}$ & $>160$ & 1 \\
\hline $\begin{array}{l}\text { Cassia EA + Dibe } \\
(\mathrm{MIC} / 2)\end{array}$ & 1.25 & 4 & $\begin{array}{l}\text { Cassia EA }+ \text { Chl } \\
(\mathrm{MIC} / 2)\end{array}$ & 0.625 & 8 & $\begin{array}{l}\text { Cassia EA }+ \text { To } \\
(10 \mu \mathrm{g} / \mathrm{ml})\end{array}$ & $>160$ & 1 \\
\hline $\begin{array}{l}\text { Cassia EA + Dibe } \\
(\mathrm{MIC} / 4)\end{array}$ & 2.5 & 2 & $\begin{array}{l}\text { Cassia EA + Chl } \\
(\mathrm{MIC} / 4)\end{array}$ & 1.25 & 4 & $\begin{array}{l}\text { Cassia EA }+ \text { To } \\
(20 \mu \mathrm{g} / \mathrm{ml})\end{array}$ & $>160$ & 1 \\
\hline $\begin{array}{l}\text { Cassia EA + Dibe } \\
(\mathrm{MIC} / 8)\end{array}$ & 5 & 1 & $\begin{array}{l}\text { Cassia EA + Chl } \\
(\mathrm{MIC} / 8)\end{array}$ & 5 & 1 & $\begin{array}{l}\text { Cassia EA }+ \text { To } \\
(40 \mu \mathrm{g} / \mathrm{ml})\end{array}$ & $>160$ & 1 \\
\hline $\begin{array}{l}\text { Cassia EA + Dibe } \\
(\mathrm{MIC} / 16)\end{array}$ & 5 & 1 & $\begin{array}{l}\text { Cassia EA + Chl } \\
(\mathrm{MIC} / 16)\end{array}$ & 5 & 1 & $\begin{array}{l}\text { Cassia EA }+ \text { To } \\
(80 \mu \mathrm{g} / \mathrm{ml})\end{array}$ & $>160$ & 1 \\
\hline Cassia EA + Dibe & 5 & 1 & Cassia EA + Chl & 5 & 1 & Cassia EA + To & $>160$ & 1 \\
\hline
\end{tabular}




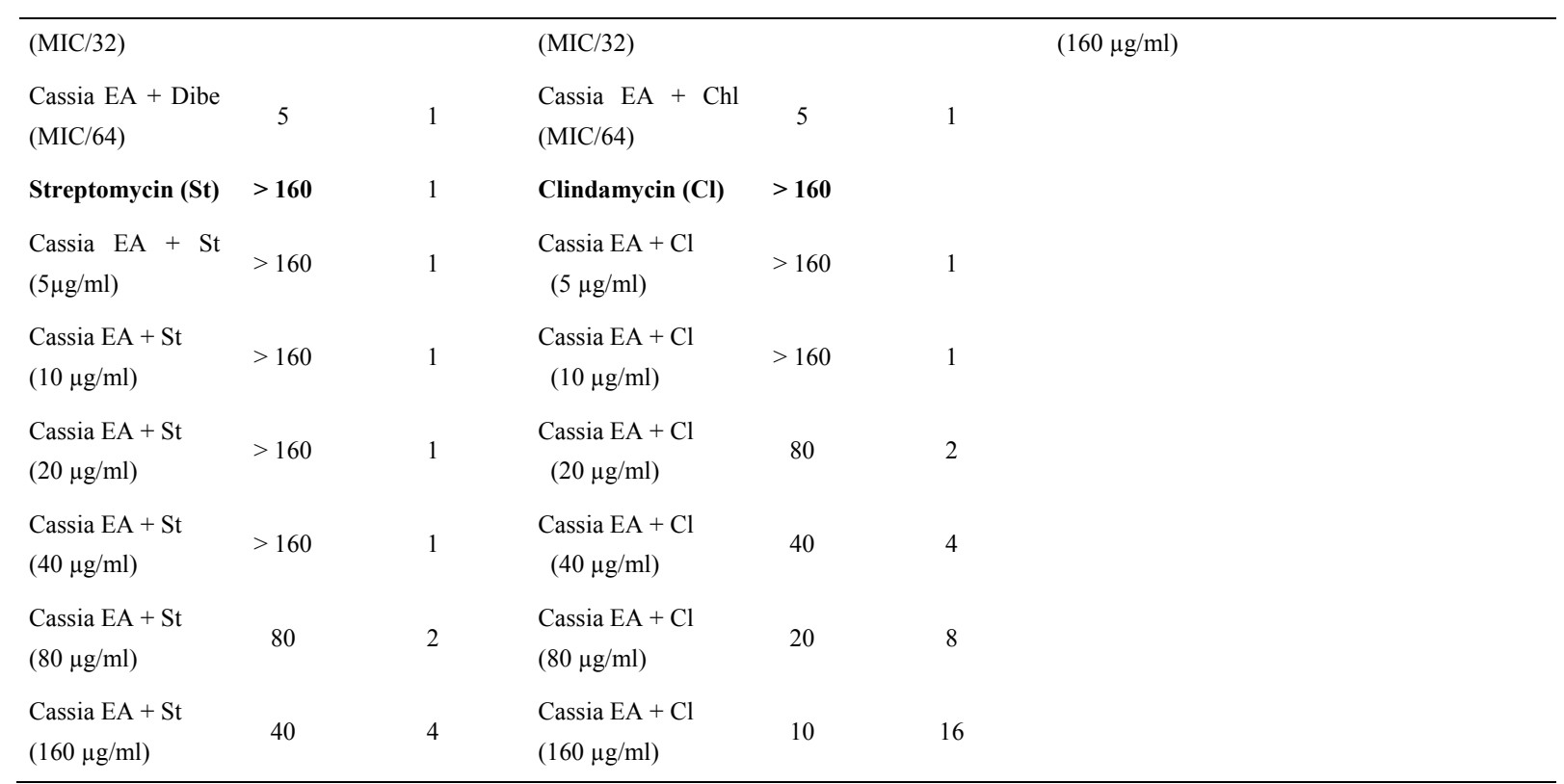

Streptomycin (St), gentamicin (Genta), tobramycin (To), kanamycin (Kana), netilmicin (Net), spectinomycin (Spet), chloramphenicol (Chl), doxycycline monohydrate (Doxy), clindamycin (Cl), erythromycin (Er) dibecacine (Dibe). Cassia AE: ethyl acetate extract of Cassia arereh, Minimum inhibitory concentration (MIC).

\section{Discussion}

Some of the plant-extracts studied here were effective against the strains of $V$. cholerae O1. These results support the traditional use of these plants to treat gastrointestinal infections. To the best of our knowledge, the plant extracts used in this study are being shown for the first time to demonstrate bactericidal activity against $V$. cholerae O1. Synergism effect resulting from the combination of antimicrobial agents with crude plant extracts was verified. Our results were consistent with previous in vitro studies which reported synergistic effects with significant reduction in the MICs of the antibiotics due to combination of different antimicrobial agents with different crude plant extracts against microorganisms (Aqil et al., 2005; Betoni et al., 2006; Braga et al., 2005; Esimone et al., 2006; Yang et al., 2005; Yam et al., 1998) and stand out as veritable sources of potential resistance modifying agents (Dickson et al., 2006; Gibbons et al., 2003; Sibanda et al., 2007). The change in MIC was noticed even with antibiotics showed weak antibacterial activity. The decrease in MIC to test antimicrobial agents could be referred to that the crude extract has many different phytochemicals which might inhibits bacteria in different mechanism. This double attack of both agents on different target sites of the bacteria could theoretically lead to either additive or a synergistic effect (Esimone et al., 2006).

In conclusion, this study probably suggests the possibility of concurrent use of these antimicrobial drugs and extracts in combination in treating infections caused by $V$. cholerae strains or at least the concomitant administration of these plants and antimicrobial drugs may not impair the antimicrobial activity of these antibiotics. The results obtained were encouraging, although clinical controlled studies are needed to define the real efficacy and possible toxic effects in vivo. Further research is to be carried out to increase in the number of drugs, increase number of clinical isolates and identify the effective compounds in the crude extract $t$, in order to establish the mode of action against the $V$. cholerae isolate and the development of pharmacological agents to treat cholera using medicinal plants.

\section{Acknowledgement}

We are grateful to the Bacteriology and Mycology Laboratories of Centre Pasteur Yaoundé for given us $V$. cholerae strain.

\section{References}

Abo, K. A., Adediwuna, A. A., \& Ibikunte, A. J. (1998). $1^{\text {er }}$ atelier international à base de plantes médicinales (pp. 22-24). l'université d'Ibadan, Ibadan Nigeria. Londres.

Adjanohoun, J. E., Aboubakar, N., Dramane, K., Ebot, M. E., Ekpere, J. A., Enow-orock, E. G., ... Wirmum, C. K. (1996). Contribution to Ethno botanical and Floristic studies in Cameroon: Traditional Medicine and 
pharmacopoeia (pp. 60-61). Technical and research commission of organization of African Unity (OAU/STEC).

Adwan, M. G., Abu-Shanab, A. B., \& Adwan, M. K. (2008). In vitro activity of certain drugs in combination with plant extracts against Staphylococcus aureus. Pak. J. Med, 24, 541-544.

Aqil, F., Khan, M. S. A., Owais, M., \& Ahmad, I. (2005). Effect of certain bioactive plant extracts on clinical isolates of \$-lactamase producing methicilin-resistant Staphylococcus aureus. J. Basic Microbiol, 45, 106-114.

Bauer, A. W., Kirby, W. M., Sherris, J. C., \& Jurck, M. (1996). Antibiotic susceptibility testing by a standardized single disc method. American J Pathol, 45, 493-496.

Betoni, J. E., Mantovani, R. P., Barbosa, L. N., Di Stasi, L. C., \& Junior, A. F. (2006). Synergism between plant extract and antimicrobial drugs used on Staphylococcus aureus diseases. Mem. Inst. Oswaldo Cruz, Rio de Janeiro, 101, 387-390.

Braga, L. C., Leite, A. A. M., Xavier, K. G. S., Takahashi, J. A., Bemquerer, M. P., Chartone-Souza, E. \& Nascimento, A. M. A. (2005). Synergic interaction between pomegranate extract and antibiotics against Staphylococcus aureus. Can. J. Microbiol, 51, 541-547.

Diallo. (2000). Ethnopharmocological survey of medical plants in Mali a phytochemical study of four of them Glinus oppositifolius (Aizoaceae), Diospyros abyssinica (Ebenaceae), Entada africana (Mimosaceae), Trichilia emetica (Méliaceae). These de Doctorat, Lausanne, 148-176.

Dickson, R. A., Houghton, P. J., Highlands, P. J., \& Gibbons, S. (2006). Antimicrobial, resistance-modifying effects, antioxidant and free radical scavenging of Mezoneuron benthamianum Baill, Securinega virosa Roxb. and Wlld. and Microglossa pyrifolia Lam. Phytother Res., 20, 41-45.

Edward, D. I. (1980). Antimicrobial Action (1st ed., pp. 8-30). The Macmillan Press London and Basingstoke.

Esimone, C. O., Iroha, I. R., Ibezim, E. C., Okeh, C. O., \& Okpana, E. M. (2006). In vitro evaluation of the interaction between tea extracts and penicillin $\mathrm{G}$ against staphylococcus aureus. Afr. J. Biotechnol, 5, 1082-1086.

Gibbons, S. M., Oluwatuyi, N. C., \& Veitch Gray, A. I. (2003). Bacterial resistance modifying agents from Lycopus europaeus. Phytochemistry, 62, 83-87.

Heymann, D. L. (2004). Control of Communicable Diseases Manual (18 th ed). Washington: American Public Health Association.

Kochar, S. L. (1981). Cultures tropicales : un manuel de botanique économique Londres. In M. C. Millan (Ed. p. 416), du Collège International.

Nascimento, G. G. F., Locatelli, J., Freitas, P. C., \& Silva, L. (2000). Antibacterial activity of plant extracts and phytochemicals on antibiotic-resistant bacteria. Braz. J. Microbiol, 31, 247-256.

NCCLS. (1999). Methods for determining bactericidal activity of antimicrobial agents. Approved guideline, M26-A. National Committee for Clinical Laboratory Standards, Wayne, Pa.

NCCLS. (2002). Performance standards for antimicrobial disk susceptibility testing, 12t informational supplement. NCCLS document, M100-S12. National Committee for Clinical Laboratory Standards, Wayne, Pa.

Sack, D. A., Sack, R. B., \& Siddique, A. K. (2004). Cholera. Lancet, 363, 223-33.

Sibanda, T., \& Okok, A. I. (2007). The challenges of overcoming antibiotic resistance: Plant extracts as potential sources of antimicrobial and resistance modifying agents. Afr. J. Biotechnol, 6, 2886-2896.

Thakurta, P., Bhowmik, P., Mukherjee, S., Hajra, T. K., Patra, A., \& Bag, P. K. (2007). Antibacterial, antisecretory and antihemorrhagic activity of Azadirachta indica used to treat cholera and diarrhea in India. J Ethnopharmacol, 111, 607-612.

World Health Organization. (2009). Cholera. Wkly Epidemiol Rec., 31, 293-308.

World Health Organization. (2010). Cholera vaccines: WHO position paper. Wkly Epidemiol Rec., 85, 117-28.

Yam, T. S., Hamilton-Miller, J. M., \& Shah, S. (1998). The effect of a component of tea (Camellia sinensis) on methicillin resistance, PBP2 synthesis and beta-lactamase production in Staphylococcus aureus. $J$. Antimicrob. Chemother, 42, 211-216. 
Yang, Z. C., Wang, B. C., Yang, X. S., Wang, Q., \& Ran, L. (2005). The synergistic activity of antibiotics combined with eight traditional Chinese medicines against two different strains of Staphylococcus aureus. Colloids Surf B Biointerfaces, 41, 79-81.

\section{Copyrights}

Copyright for this article is retained by the author(s), with first publication rights granted to the journal.

This is an open-access article distributed under the terms and conditions of the Creative Commons Attribution license (http://creativecommons.org/licenses/by/3.0/). 